\title{
Representing creation, experiencing the sublime: The Longinian tradition in Tasso and Milton
}

\author{
Irene Montori \\ Sapienza U niversità di Roma, Italy
}

\begin{abstract}
This essay aims to demonstrate how Tasso and Milton were conscious of the Longinian tradition and aware of fashioning a poetry of the sublime when rewriting the story of creation. The author of II mondo creato incorporates the Longinian model of sublime ekstasis into his concept of meraviglia to construct his own poetics of artistic creation. Despite Milton's indebtedness to Tasso, in Paradise Lost the English poet distances himself from a full commitment to Longinian ekstasis and locates the sublime in a more dialogical, if not dialectical, compositional model of poetic creation. From a broader perspective, this paper aims to illustrate the centrality of the sublime in fashioning early modern literary poetics.
\end{abstract}

KEYWORDS: Tasso; Milton; creation; wonder; the sublime.

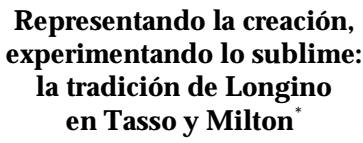

RESUMEN : Este artículo pretende demostrar cómo Tasso y Milton eran conscientes dela tradición longiniana y a la vez de estar creando una poesía de lo sublimeal reescribir la historia de la creación. El autor de II mondo creato incorpora el modelo longiniano del ekstasis sublime a su concepto de meraviglia para construir su propia poética de creación artística. A pesar de la deuda de Milton para con Tasso, en Paradise Lost el poeta inglés se distancia de un compromiso total con el ekstasis longiniano y ubica lo sublime en un modelo composicional más dialógico, si no dialéctico, de creación poética. Desde una perspectiva más amplia, este artículo intenta ilustrar la centralidad de

\section{Representar a criação, experienciar o sublime: A tradição Longiniana em Tasso e Milton ${ }^{* *}$}

RESUMO: Este artigo visa demonstrar como Tasso e Milton estavam autoconscientes da tradição longiniana e cientes de desenvolverem uma poesia do sublime ao reescreverem a história da criação. O autor dell mondo creato incorpora o modelo longiniano de ekstasis sublime no seu conceito de meraviglia para construir a sua própria poética da criação artística. A pesar da dívida de Milton para com Tasso, em Paradise L ost o poeta inglês afasta-se de um compromisso total com a ekstasis Ionginiana e localiza o sublime num modelo composicional mais dialógico, se não mesmo dialético, da criação poética. Em termos mais amplos, este artigo procura ilustrar a centralidade do

*Translation into Spanish by Tamara Pérez-Fernández.

** Translation into Portuguese by Miguel Ramalhete.

$$
\text { (C) ederi } 30 \text { (2020): 69-89 }
$$

https:/ / doi.org/ 10.34136/ sederi.2020.4 
lo sublime en la creación de la poética literaria moderna.

PALABRAS CLAVE: Tasso; Milton; creación; maravilla; lo sublime. sublime na formação da poética literária da idade proto-moderna.

PALAVRAS-CHAVE: Tasso; Milton; criação; maravilha; o sublime.

\section{The making of the sublime in the Fiat LuX}

In chapter nine of his famous tractate $\mathrm{O}$ the Sublime (Peri H ypsous), Longinus quotes the fiat lux passage from Genesis in order to define what the sublime is. By praising the exceptionality of the author of Genesis ("no ordinary man"), Longinus remarks that "[M oses] writes at the very beginning of his Laws: 'God said'-what? 'let there be light,' and there was light, 'Let there be earth,' and there was earth" (9.2). The quotation from Genesis 1.3 is of undeniableinterest, not only for the presence of the Scriptures in a Hellenistic rhetorical tract, but also because Longinus suggests the author's inventive power to construct a poetics of transcendence. What Longinus points out as exceptional is not Moses' rhetorical ability to represent God's creation, but-through his interrogative ("what?")-Moses' mastery to upstage the experience of creation with a sublimity analogous to that performed by God in bringing the world into existence (Porter 2016). The sublime is, therefore, the magnanimous power of the writer to produce a transcendental experience in himself and in the reader alike. The fiat lux passage exemplifies how the author of Genesis recreates in the text an experience of wonder and astonishment, which is comparable to the amazement caused by God's creation in nature.

The link between the fiat lux and the notion of sublimity regains importance again in modernity when the $P$ eri $\mathrm{H}$ ypsous reemerges with Nicolas Boileau's French translation, T raitédu sublime ou du merveilleux dans le discours, in 1674. In this treatise, Boileau considers the fiat lux to be the hallmark of true sublimity for its simplicity, so much so that fiat lux is the only quoted passage from Longinus's text. However, Boileau's most influential imperative on Longinus is his distinction between the sublime styleand the experiential sublime. In addition to its rhetorical meaning, the sublime, for Boileau, is an elevating experience for the reader as a result of the writer's magnanimous mind: the sublime, he claims, "enlève, ravit, transporte" (318).

Despite the centrality of Boileau's interpretation, the Longinian text circulated long before the French translation, starting with Francesco Robortello's editio princeps (1554), which contributed to the 
revival of the sublime in conceptual and experiential patterns. ${ }^{1}$ With the availability of the Hellenistic treatise in the sixteenth century, Renaissance writers incorporated the Longinian idea of the sublimeas ravishment, elevation, and transport in their imagery (Cheney 2018). In this regard, Tasso's II mondo creato (1594, published posthumously in 1607) and Book 7 in Milton's Paradise Lost (1667) are two of the most representative examples of how Renaissance authors merged the sublime, as an experience of transcendence, with the account of biblical creation. Both texts belong to modern hexameral literature, which represents poetic creation as anal ogous to the divine making of the world. ${ }^{2}$ By celebrating the beauty and variety of the created universe, hexameral poetry also praises the ability of the poet to represent the experience of God's molding process. Tasso's and Milton's poems celebrate the wonders in nature and identify the narration of origins as the source of an experience of the divine. ${ }^{3}$

The account of creation in II mondo creato represents the poet's occasion for transport, namely, his ability to transcend to mental and moral heights: "Così chi di celesti obietti eterni | E de le cose smisurate e grandi | Mira le meraviglie," that is, the poet, "Convien cheseco, anzi in sé stesso, apporti| Gli impeti interni, e'I vivo ardore,

\footnotetext{
${ }^{1}$ For an expanded history of the reception of Longinus's Peri Hypsous see Fumaroli (1986) and Goyet (1991).
}

${ }^{2}$ Hexameral literature was a popular genre in the early church and the Middle Ages. Basil of Caesarea wrote a commentary on Genesis in his Exameron, which became the source of Saint Ambrose's H exameron, and Saint Augustine wrote D e Genesi ad litteram on the first three chapters of Genesis. Though not an hexameral poem, Dante's Divina commedia alludes to biblical creation throughout his poem. In light of the new astronomical and geographical discoveries, poetry about Creation reaches a climax between 1562 and 1667, starting with MauriceScève's M icrocosmeand Guillame Sall luste Du Bartas's La sepmaine, ou Création du monde (1578) in France. Du Bartas's hexameral poem inspired Tasso, who read La sepmaine in its Latin version. A lonso de A vecedo uses Du Bartas's and Tasso's poems as models for his De la Creación del M undo (1615). Milton's account of the creation in Book 7 of Paradise Lost concludes this prolific period for hexameral literature (Boitani 2007, 79-90).

${ }^{3}$ Given that Tasso and Milton write in a period antecedent to the eighteenth-century theorization of the sublime, it is important to differentiate the specific term "sublime" from a poetics of the sublime, including an array of ideas, images, themes, and patterns. For clarity, I will use Patrick Cheney's working definition of the Longinian sublime as literary greatness $(2018,16)$. By literary greatness, Longinus means artistic excellence in creating an experience of transport in the character, the author, and the reader alike. In other words, true grandeur in literature activates the transformative potential of the human mind to reach beyond immanence. 
e "I zelo | Fervido, a contemplar rivolto e fisso | Tai cose e tante" (4.14-22). " "Impeti interni," "vivo ardore," "zelo fervido" areall terms that describe meraviglia as the poet's intuitive experience of creativity and elevation and evoke Longinus's effects of transport and wonder from the genius to his audience. ${ }^{5}$

Following the Longinian tradition, Milton reveals his intention to compose his story of the origins in a sublime style: "I thence | Invoke thy aid to my advent'rous song,| That with no middle flight intends to soar| Above the Aonian mount, while it pursues | Things unattempted yet in prose or rhyme" (Paradise Lost, 1.12-16). The English poet declares that his subject matter is manifestly sublime ("advent'rous" and "unattempted") 6 and, therefore, demands a lofty style. ${ }^{7}$ A longside Tasso, Milton understands the sublimity of biblical creation not only in terms of elevated diction, but also as an experience of transcendence. However, despite his indebtedness to Tasso, the author of Paradise L ost chooses not to represent the creation in Book 7 as a source of ecstatic elevation and interpretation. Rather, Milton locates the sublimity of art and nature in a more dialogical, if not dialectical, compositional model.

Rooted in the Longinian combination of artistic and divine creation within the sublime, II mondo creato and Paradise Lost share the same premise in their representations of God's fashioning of the world. Their paths to sublimity, however, differ greatly and these divergences will be the object of scrutiny in the present essay.

\footnotetext{
${ }^{4}$ English translation from Tusiani in Tasso (1982): “Thus he who gazes on the rare delights | of all these heavenly eternal things, | so mighty and so measureless and pure | [...] quickly agrees he must within himself | have the same fervor, harbor the same zeal | to contemplate with rapt attention all | such mighty things."

${ }^{5} \mathrm{O} n$ the Sublime, 1.4: "For the effect of genius is not to persuade the audience but rather to transport them out of themselves;" 8.1: "the second [source of the sublime] is the inspiration of vehement emotions."

${ }^{6}$ Theword "unattempted" translates Ariosto's expression "cosa non detta in prosa mai, né in rima" (O rlando furioso, 1.2). The Italian epic tradition and theory, along with the classical legacy, exerted a strong influence on Milton's Paradise L ost.

7 The expression "middle flight," as David Quint explains, evokes the "middle way" (medio in Latin) that both Ovid's A pollo and Daedalus recommend their sons Phaeton and I carus as the safest course to fly (M etamorphosis 2.137, 8.203). In this regard, Milton distances himself from Du Bartas's cautious invocation of the Muse for "the middle Region" (D ivine W eeks, I.1.136) in Joshua Sylvester's translation (Quint 2014, 89).
} 


\section{Meravigliaand ekstasisin Tasso}

Tasso's involvement with the Longinian tractate is still a debated question given the lack of direct references to the ancient text. However, recent work has suggested that $0 \mathrm{n}$ the Sublime might have exerted an influence on Tasso's poetic theory either directly through Robortello's editio princeps (1554) and Pagano's Latin translation (1572), or indirectly through the many allusions to Longinus in the commentaries by Pietro Vettori (Commentary on A ristotle, 1560; Commentary on Demetrius, 1562) and Francesco Patrizi (D ella Poetica, 1586) (Graziani 1996, 122-23; Doran 2015, 104; Lehtonen 2016, 455). This is not to neglect the importance of other Hellenistic rhetoricians such as Demetrius or to deny the presence of A ristotelian thought in Tasso's poetic theory, but to suggest that, in his later career, Tasso's idea of literature was also informed by some Longinian elements. Tasso drew on the Longinian model of the sublime and incorporated it into his concept of meraviglia merging it with the pattern of divine and artistic creation.

Tasso's meraviglia was an idea that developed over time in his career from his prose writing, Discorsi del poema eroico, published in the same year he most likely concluded II mon do creato, his last work. The understanding of wonder, marvel, and admiration in the Renaissance, according to the orthodox perspective, was based on Aristotle's M etaphysics and Poetics (Platt 1992, 387-88). Francesco Robortello, Antonio Minturno and Giovambattista Giraldi Cinthio maintained that wonder was a necessary component in poetry and was most effective when marvelous moments occurred unexpectedly (Aristotle's P oetics 1452a). Tasso made wonder the hallmark of epic poetry, which he defined as the imitation of a noble action, narrated in the loftiest style and with the purpose of "muovere gli animi con la maraviglia, e di giovare in questa guisa" (D iscorsi, 508). ${ }^{8} \mathrm{M}$ eraviglia, for Tasso, is the final aim of the epic genre not merely because of aesthetic pleasure. The Italian poet invokes a much more complex experience than delight ("giovare") when using the term "wonder": meraviglia makes the readers "attoniti" [astonished] (506) and fills their minds "di tumulto e di perturbazione" [with turmoil and perturbation] (712). In other words, wonder is the author's capacity to

${ }^{8}$ D iscourses, 17: "moving the mind to wonder and thus being useful." 
create an experience of transport that overwhelms the reader. In a similar vein, Longinus affirmed in his tract:

what inspires wonder, with its power of amazing us, al ways prevails over what is merely convincing and pleasing. For our persuasions are usually under our own control, while these things exercise an irresistible power and mastery, and get the better of every listener. (On the Sublime, 1.4)

Longinus places the irresistible power to astonish in the author's nobility of mind. In the same chapter in which the fiat lux citation is found, Longinus claims that "sublimity is the echo of a noble mind" (9.2). The author's capacity to excite wonder depends less on his technical skills than on his genius, his magnitude animi. Analogously, meraviglia in Tasso invokes, as Françoise Graziani explains, the "pouvoir contenu dans l'altezza d'ingegno du poète" (1996, 131). ${ }^{9}$ The poet's intellectual height ("altezza"), which recalls Longinus's term for sublimity hypsos (Doran 2015, 105), is infused by God and emanates from the genius to his audience:

O possa io pur, sì come guida e scorta

Ch'ignoto peregrin conduce intorno,

E gli edifici ele mirabili opre

Di famosa città gli addita e mostra,

Così condur le peregrine menti

De' mortali, qua giù mai sempre erranti,

A le sublimi meraviglie occulte

Di questa ampia città, di questa io dico

Città celeste, ove è la patria antica

Di noi figli d'Adamo, el'alta reggia

In cui gli eterni premi il Re comparte. (II mondo creato, I.76-86) ${ }^{10}$

For Tasso, it is through the emulation of the genius's mind that the reader is raised to a higher mental plane, reaching the vision of the sublime, heavenly city. M eraviglia represents the contemplative experience of elevation whose effects reverberate from the inspired poet to his audience: “Cosi possiam ne l'invisibil luce | Conoscere il

\footnotetext{
${ }^{9}$ Tasso uses the expression al tezza d'ingegno in his Lezione sopra un sonetto di monsignor D ella Casa (Tasso 1875, 122).

10 "And may I also, likea leading guide | who to an unknown passenger makes known | the palaces and wondrous monuments| of a most famous city, now escort| themortal minds till tarrying on earth | to the sublime, concealed magnificence | of this wide City-the celestial Home | that is the ancient fatherland of all | the sons of Adam, and the lofty court where| the King bestows his heavenly rewards."
} 
gran Dio che fece il mondo, | Come dal contemplar la nostra mente | A conoscer la sua leviamo in alto" (6.1615-18). ${ }^{11}$

Tasso's notion of imitation resembles Longinus's concept of zelosismimesis ( $0 \mathrm{n}$ the Sublime, 13.2), rather than Aristotle's concept of imitation. Just as Longinus understands emulation as a competition between past models and the poetic desire for innovation, ${ }^{12}$ the contemplation of the created world in II mondo creato is compared to the physical competitions in tournament and joust ("le contese," "i duri incontri," 4.1, 6). Before the contest, the observer feels "un movimento interno | Ond'è commosso e concitato insieme con quei che fan tra loro duro contrasto" (4.7-9). ${ }^{13}$ Like the Longinian sublime, Tasso's meraviglia is measured by its forcefulness and the powerful effect it exerts on the reader rather than by its rhetorical ornament and exalted eloquence.

Furthermore, a new linguistic and formal phase is inaugurated in II mondo creato, under the influence of Longinus's fiat lux. ${ }^{14} \mathrm{M}$ eraviglia is found in the wonders of creation, as in the fiat lux passage, instead of in the unexpected, the incredible, or the monstrous as in the Gerusalemme liberata (Leo 1954, 9-10). The variatio of style does not hinge on overabundance and the multiplicity of tones; it is not shaped on the contrasts generated by oxymorons, antitheses, and paradoxes, as in the Liberata; rather it is modulated by a regular and rhythmical cadence of language, which privileges repetition in any form (Leo

11 "We in the light invisible at last | can know the mighty Maker of the world | if with our minds we soar to contemplate| His lofty thought."

${ }^{12}$ Longinus clearly expresses the agonistic dynamic of imitation in his description of Plato's brilliant style. Plato would never have achieved his mastery in the philosophical doctrines nor his grandeur in language, Longinus maintains, "had he not striven, with heart and soul, to contest the prize with Homer, like a young antagonist with one who had al ready won his spurs [...] the fight for fame well worth the winning, where even to be worsted by our forerunners is not without glory" ( $0 n$ the Sublime, 13.4). For Milton's notion of the sublime as a dialectic competition see further in this article.

13 "H efeels in his soul a deep enthusiasm | that agitates and rouses all of him | together with the men who fiercely fight."

${ }^{14}$ Before citing the Old Testament, Longinus celebrates Homer's superior ability to produce admiration and powerful emotions in a simple image such as Ajax's silence in the 0 dyssey (11.549-64) without necessarily using an elevated diction or bombastic el oquence ("thoseempty inflations, void of sincerity," O n the Sublime, 3.2): "How grand, for instance, is the silence of Ajax in the Summoning of the Ghosts, more sublime than any speech!"(9.2). A similar modus scribendi, that is, a simpler, unadorned style, characterizes Tasso's last work. 
1954, 15). In terms of style, iterative does not mean monotone or monothematic; in fact, Tasso preserves the idea of variety in the created world. Yet, he gives new shape to multiplicity by placing it in a unified and orderly language. The more uniformed language of II mondo creato reproduces the language of the Bible: it is condensed, sober, sacral and highly iterative, particularly in the account of creation (resembling the phrases in Genesis: "God said," "God saw that it was good").

Iteration in all its forms-anaphora, epistrophe, anadiplosis, amplifications and accumulations-is indeed the dominant rhetorical figure in Tasso's work on creation: "un sistema retorico geminativo," as Rosanna Morace has defined it, a language that magnifies itself through repetition $(2016,133)$. This is the rhetorical property of Tasso's fiat lux in the first day of the creation of the world:

E disse, Fatta sia la luce; et opra

Fu il detto al comandar del Padre eterno,

Né'I suo parlar suon di snodata lingua

Né percossa fu già chel'aria imprima

Di sé medesma, e di sua voce informi,

Ma del santo Voler, ch'a l'opre inchina,

Quell'inchinarsi è la Parola interna.

Così la prima voce e'I primo impero

Del gran Padre del cielo criò repente

La chiarissima pura ebella luce

Che fu prima raccolta, e poi divisa

E 'n più lumi distinta il quarto giorno. (II mondo creato, I.533-44) ${ }^{15}$

Repetition characterizes every aspect of the passage. Epanalepsis connotes the very beginning of God's creation of light: disse, detto. The word "dire" is a key verb in the process of creation and its significance is reiterated through the use of words belonging to the same semantic area: "parlar," "suon," “lingua," "voce," "Parola," and again "voce." The effects of God's utterances are marked by the anaphora of "neither" né il suo parlar | né percossa fu, the alliteration of the same

\footnotetext{
15 “He said, 'Let there be light!' His word was law, | for the Eternal Father is obeyed. | But, though resembling a full-sounding tongue, | his word was not a blow that prints itself | upon theair and shapes it with its voice: | it was his holy will's innermost sound | which he bent down into activity. | Thus the first voice and thus the first command | of the great Heavenly Father made at once | the purest, and the clearest, fairest light, | which first was held together, and then split | in several separatelights on the fourth day."
} 
prefix in- ("imprima," "informi," “inchina”), by epanalepsis ("opra," "opre"; "inchina," "inchinarsi") and the insistence of the adjective "first" ("prima voce," "primo impero," "prima raccolta"). Looking at the text from a phonic approach, the representation of light is forged on an alliterative chain with the letter ' $s$ ': "Né 'I suo parlar suon di snodata lingua | Né percossa fu già che l'aria imprima | Di sé medesma, e di sua voce informi, | Ma del santo Voler, ch'a l'opre inchina, | Quell'inchinarsi." God's light emanates like a whisper, which is pronounced with a single, uninterrupted voice and, in doing so, the Father causes the creation of the world by diffuse reflection. God is light, and he manifests himself in the universe through the reflection of his own light: "O bellissima luce, o luce amica | De la natura e de la mente umana, | De la divinità serena imago" (1.56264). ${ }^{16}$

In a letter addressed to Scipione Gonzaga written in 1578, the same year Tasso was imprisoned in Sant'Anna, which also marks the beginning of his religious crisis leading to the writing of II mon do creato (Luparia 1987), the poet maintains that, "non potendo affisar gli occhi nel sole, rimira ne l'acqua l'imagine de la sua luce" (Lettere, 123). Unlike Paul or Moses, he is denied the privilege of seeing God "a faccia a faccia." Instead, "in guisa d'uomo" [like a man], he is permitted to see the reflection of divine light in the things God created. It is no coincidence that the verb Tasso uses, "rimirare," to explain the way mankind gains knowledge of God-by gazing at the reflected image of his light-is formed from the prefix ri-, whose function is to reiterate the meaning of the verb it accompanies, and from the verb "mirare," to gaze attentively and, often, with wonder, as in Dante's "rimirando in Dio" (Paradiso VIII.90). Therefore, "rimirare," to gaze with admiration (a synonym of "ammirare," to look with admiration), does not merely produce surprise at the magnificence of the created universe; it denotes more than a poetic emotion or an aesthetic pleasure. The verb "rimirare" describes, according to Tasso, the cognitive process of contemplative admiration through which God is revealed. For the poet, to feel wonder is to experience, by analogy, the same enthusiasm and grandeur of the act of creation and, through reflection of wonder, to know the essence of the divine. The act of "rimirare," in other words, combines an intense

16 "O beatific luster, friendly light | of nature and man's mind, sweet image of | divinity." 
and transformative moment of wonder with an experience of enhanced comprehension of transcendence. Within this single experience, Tasso merges the cognitive aspect of Plato's and A ristotle's thaumaston with the Longinian ekstasis ${ }^{17}$ and the Christian experience of religious rapture. ${ }^{18}$ Tasso's artistic creation might be described as a poetics of illumination and, for this reason, Francesco Guardiani has claimed that "light" is the most recurrent word in the poem $(1986,220)$.

Yet, II mondo creato does not culminate in a circuitus spiritual is that unites God with the world. Divine essence is ultimately defined in terms of "invisibil luce" (II mondo creato, 6.1615, 7.375) so much so that the poem concludes with a sublimely tragic prayer to the Deus absconditus: "Dove sei? dove sei, chi mi ti asconde? | Chi mi t'invola, o mio Signore e Padre?" (7.1111-12). ${ }^{19}$ The end of creation engenders a sense of new beginning: this will be the time when the Deus absconditus answers the world's prayer. Tasso's questioning of God is not the result of his individual distress, the voice of a tired and melancholic author at the end of his poetic career. Instead, the end of II mondo creato embodies a more collectiveawareness about the closure of an era affected by religious and social skepticism (Scianatico 1994, 81), a world that Tasso describes as "stanco e veglio" ("weak, aging world" 7.1124).

${ }^{17}$ Ekstasis, for Longinus, occurs when the individual is drawn to a higher level of knowledgethrough intuition. This process of spiritual growth connects the subject with the grandeur of the universe and with a transcendental reality. Cf. Halliwell (2012, 330 ff.).

${ }^{18}$ Erminia Ardissino has eloquently explained thefunction of wonder in Tasso's poetics. Although she refers to Tasso's theorization of wonder in the D iscorsi, her definition of Tasso's poetics of meraviglia also applies to II mondo creato (2003, 23-24): “L'ingresso dell'elemento gnoseologico nei Discorsi dell'artepoetica, [...] si rivela [...] nelleriflessioni sul meraviglioso [...] fondando poesia e sapere. [...] meraviglia implica il superamento dell'ordine puramente estetico delle cose e della storia per congiungerlo con l'ordine metafisico, oltre che etico. La meraviglia è sorpresa per il mistero e desiderio di comprenderlo, risveglia interesse per la dimensione che è velata dietro ciò che la desta. La riflessione sul meraviglioso trova l'al tro in accordo Platone con A ristotele, attenti al valore cognitivo del thaumaston [Cf. Platone, Teeteto 155d; Aristotele, M etafisica 282d], ma apre anche alla fede per la soluzione del «maraviglioso cristiano». La meraviglia pone in concordia verosimile e sublime, verità e fantastico, unità e varietà, sensi e intelletto: è l'incontro della dimensione sensibile con quella intellegibile."

19 "Where are You? Oh, where are You? | Why do You hide from me, or who or what | takes You from meaway, my Lord and Father?" 


\section{The construction of the sublime in Paradise Lost 7}

Tasso's lasting impression of the end as a new beginning lays the foundation for Milton's Paradise Lost, a poem that imagines the creation of the world from the perspective of its end. While one would expect to read about the creation of the world at the beginning of the poem, creation is not fully described until Book 7, after the account of the angelic fall. This inversion of the biblical order is repeated throughout the poem: first it is seen through the angelic fall in Books 1 and 2 followed by Uriel's account of creation in Book 3; then Raphael recalls the war in heaven and the fall of the rebellious angels in Book 6 followed by his creation narrative in Book 7; then the fall of A dam and Eve in Books 9 and 10 is followed by Michael's disclosure of a new creation and the coming of our first parents into the world in the final books (Schwartz 1993, 2-3). As for Longinus's interpolation in the fiat lux passage ("God said" - what?), Milton's variation from the order of the Scriptures foregrounds a process of re-creation. Literary creation is, for Milton, an act of origin, but every poetic act is also a repetition, a re-presentation, a re-production. Therefore, to write about the biblical origin is al so to write about the biblical origins in the Scriptures and to recount the many rewritings that preceded Paradise Lost.

Milton had read Tasso and included the Italian author among his models for epic poetry (The Reason of Church Government in CPW 1, 813). ${ }^{20}$ Certainly, Milton had $\mathrm{II}$ mondo creato in mind when he composed the invocation to light in Book 3 of Paradise L ost: " Hail holy light, offspring of heaven first-born, | Or of the eternal co-eternal beam | May I express thee unblamed?" (3.1-3). The first two verses echo the protasis of Tasso's creation poem, which celebrates the coeternity of the Son to his Father: "Padre del Cielo, etu del Padreeterno | Eterno figlio, e non creata prole" (1.1-2). The style of the passage is very similar to the fiat lux description in II mondo creato:

Hail holy light, offspring of heaven first-born,

Or of the eternal co-eternal beam

May I express thee unblamed? Since God is light,

And never but in unapproached light

\footnotetext{
${ }^{20}$ Many critics have illustrated the debt of Milton to Tasso for epic theory and practice, although they focused on the relation between Paradise Lost and Gerusalemme liberata, see Steadman (1976), Patterson (1971), Kates (1983), Quint (2014). Lehtonen (2019) has recently discussed the presence of the sublime in the two epic poems.
} 
Dwelt from eternity, dwelt then in thee,

Bright effluence of bright essence increate.

Or hearst thou rather pure ethereal stream,

Whose fountain who shall tell? Before the sun,

Before the heavens thou wert, and at the voice

Of God, as with a mantle didst invest

The rising world of waters dark and deep,

Won from the void and formless infinite. (Paradise Lost, 3.1-8)

There are many patterns of repetitions: the alliteration of $h$ in verse 1 ("H ail holy light, offspring of heaven first-born"); epanalepsis ("light" is repeated three times in the first four verses; verse 5: "dwelt: dwelt"; verse 6: "bright: bright"); epistrophe (again "light" at theend of verses 3 and 4 and the prefix in-: "increate," "invest," "infinite"); polyptoton (eternal in verse 2 is repeated with a different function); anadiplosis ("Before the sun" / "Before the heavens"); accumulation of words within the same semantic area (light, beam, effluence; stream, fountain, waters). Similarly, Tasso's description of fiat lux heavily relies on rhetorical and rhythmic repetition, which is in fact a characteristic of the biblical style itself. Like Longinus, whom he names in his tract $0 f$ Education, Milton also recognized the sublimity of the biblical style to convey grand thoughts and images through a condensed and uniformed language. In 0 f R eformation, Milton praised "the sober, plain, and unaffected style of the Scriptures" (CPW 1,568) and in De Doctrina Christiana he favored the author of the Epistle to the Hebrews as the one who proclaims sublimely, "The generation of the divine nature is described by no one with more sublimity and copiousness than by the apostle to the Hebrews, i. 2, 3" (The Christian D octrine, 934-35). Yet, Milton added a further dimension to the bi blical pattern of iteration: he expanded the mechanism of repetition into a repetitive pattern of opposites. While, for Tasso, repetition as diffuse reflection symbolizes how divine essence is revealed in the created world, according to Milton, man experiences transcendence in the form of repeated opposites (Lieb 1970). Therefore, poetic creation in the fallen world does not operate without its opposite: destruction or un-creation. ${ }^{21}$ As soon as Milton addresses the light in Book 3, he dramatically thematizes his possible failure: "May I express thee unblamed?" The process of creation is continuously threatened by

${ }^{21}$ Un-creation threatens the process of creativity at all levels in Paradise Lost, for example, Satan symbolizes un-creation and destruction. Here I choose to focus on creation from an authorial perspective. 
moments of darkness and chaos. Thus, in the invocation to light, Milton raises the specter of his own blindness to express his fear of the failure of language:

[...] but thou;

Revisitst not these eyes, that roll in vain

To find thy piercing ray, and find no dawn

So thick a drop serene hath quenched their orbs,

Or dim suffusion veiled. (Paradise Lost, 3.22-26)

[...] but not to me returns

Day, or the sweet approach of even or morn,

Or sight of vernal bloom, or summer's rose,

Or flocks, or herds, or human face divine;

But cloud instead, and ever-during dark

Surrounds me, from the cheerful ways of men

Cut off, and for the book of knowledge fair

Presented with a universal blank

Of nature's works to me expunged and razed,

And wisdom at one entrance quite shut out. (3.41-50)

Milton's poetic ambition can be fulfilled only by inward illumination: "thou celestial light | Shine inward [...] that I may see and tell | Of things invisible to mortal sight" (3.50-51, 54-55). Yet again, the confidence in his poetic endeavor fades away by the invocation in Book 7, which announces the song of world creation (Schwartz 1993, 61). Light encounters the threat of darkness, the fiat lux narration is created out of fiat obscuritas. Milton's poetic process of re-creation originates under the threat of two vivid images of failure: one is Bellerophon (Paradise Lost, 7.17-20), who was blinded after he had tried to fly to heaven riding Pegasus, the other is Orpheus (7.32-38), whose harp and voice were drowned by the worshippers of Bacchus. Milton's fiat lux struggles against the risks of being unseen or unheard.

Writing in the wake of new worlds and the new science of Galileo, Montaigne, and Descartes, and the epistemological challenges they posed, Milton inherits a skeptical attitude towards the ability of language to convey origins at all (Ramachandran 2015, 183). The sense of ending characterizing Milton's narrative of the beginning corresponds to a cultural change in modernity within the concept of artistic invention. On the one hand, the focal point in the act of creation gradually shifts from God to the human and, for this reason, Teskey has pointed out that "Milton is the last great poet in the European literary tradition for whom the act of creation is centered in 
God" (2006, 29). This change, on the other hand, undermines the analogy between artistic and divine creation: when human inventive power no longer resembles thegreat Maker, theindividual's authority to create is critically put into question. As a result, Milton's creation stories are always mediated by accounts of accounts and by the presence of "divine interpreter[s]" (Paradise Lost, 7.72) such as the archangels. Raphael is the figure of mediation to whom God entrusts the tale of creation. A fter the prologue, A dam demands the archangel inform him, "How first began this heaven which we behold" (7.86). The creation narrative originates from its opposite: Satan's own destruction. By recounting the story of the war in heaven, as narrated in Book 6, Raphael reiterates the idea that creation depends on its opposite, "Good out of evil to create" (7.188). Thus, from Satan's fall, God "in a moment will create| A nother world" (7.154-55). In fact, the divine performative utterance of creation is pronounced by God, but it is given effect through the mediation of his Son, who would later join his nature to mankind in order to redeem their sins (3.82-83): "So spake the almighty, and to what he spakel His Word, the Filial Godhead, gave effect" (7.174-75). In one of his most sublime images, Milton describes the Son who, like an architect, holds "the golden compasses" and sets the bounds of the universe:

He took the golden compasses, prepared

In God's eternal store, to circumscribe

This universe, and all created things:

One foot he centred, and the other turned

Round through the vast profundity obscure,

And said, Thus far extend, thus far thy bounds,

This be thy just circumference, $\mathrm{O}$ world.

Thus God the heaven created, thus the earth. (7.225-32)

While creation necessarily results from fall, and good originates from evil, Raphael demonstrates that, "to create| Is greater than created to destroy" (7.606-7). Sublimity, for Milton, lies in the higher union of opposing arguments. Poetic creation is the re-presentation of a dramatic dialectic, while sublime creation is the attempt to polarize the terms of this dialectic into harmonious synthesis (Radzinowicz 1978). In this regard, Milton understands sublimity in Longinian terms as an agonistic dynamic. Although Longinus describes the author's grandeur as a secularized version of divine inspirationsublimity originates from "Zealous imitation of the great prose writers and poets of the past" ( $0 \mathrm{n}$ the Sublime, 13.2)-he emphasizes 
that emulation does not imply a passive veneration for past models. Longinus's inspirational process to create sublime poetry emerges from the rival ry between the admiration for the past and the creative urge to subvert and exceed the tradition (Doran 2015, 65-67). Theagon between admiration and deviance from the illustrious past represents the essence of sublime creation, for Longinus as well as for Milton. In this regard, David Quint has uncovered, for instance, how Book 3 pivots around the opposition between the poet's internal illumination and the Apollonian light, which inspires pagan poetry as in the Homeric H ymn to A pollo and Callimachus's H ymn to A pollo $(2014,98)$. In one of his most famous early tracts, A reopagitica, Milton affirms that in order to ascertain truth and to gain knowledge, one has to engage in the "sublimest points of controversie" (CPW 2, 557). Therefore, from an ethical standpoint, knowledge advances out of an active engagement with evil. Similarly, on a literary level, sublime poetry emerges out of a dialectical writing that displays oppositions and creates polarities. The construction of a poetics of sublimity depends on a persistent exercise of choice for the author and for the reader alike.22

In Paradise L ost, sublimity originates from the creation of dialectical patterns and, in this light, it differs from Tasso's concept of wonder as an intense emotional moment of transcendence. Indeed, Milton recognizes the importance of sublime inspiration in the poetics of creation. His deep commitment to sublime style is evident in his intention to recount "Things unattempted yet in prose or rhyme" (1.16), as he writes at the beginning of Paradise Lost, but the English author is also very conscious of the risks of flying al oft under the spell of divine inspiration. ${ }^{23}$ For this reason, he distances himself from Tasso's idea of meraviglia as a contemplative and solitary kind of

\footnotetext{
${ }^{22}$ Reading Paradise L ost as a poem about choosing is a traditional hermeneutic strategy; see Lewalski $(2003,460)$ and Fish $(2001,547)$. Yet, what has been overlooked is the relation between the poetics of sublimity and the exercise of choice in Milton's poem. A thorough analysis and discussion of the topic would require a whole book, therefore I will concentrate on the role of the author, rather than the reader, in the construction of the sublime. For the sublime as a theory of reading see Porter $(2016,117-24)$.

23 During the English Restoration, sublimity was also associated with a kind of fanaticism based on a claim of divine inspiration. Milton had polemicized with enthusiasts and fanatics in his prose works. Heshows heis fully aware that enthusiasm is potentially dangerous when associated with the claim of divine inspiration in the images of the fallen Bellerophon and the murdered Orpheus in Book 7. For the relation between enthusiasm and the sublime see Achinstein (2003, 154-81).
} 
Longinian ekstasis-a transformative and enlightening moment of consciousness. Milton's understanding of divine truths emerges from a material sublime: the Son, as the divine architect, creates the universe by number and proportion, marking thelimits of the infinite out of chaos. ${ }^{24}$ Likewise, Adam learns from Raphael that the proper method for understanding the invisible and the incomprehensible is to pore over materiality, reminiscent of Milton's writing in of Education (CPW 2, 368):

Heav'n is for thee too high

To know what passes there; be lowly wise:

Think only what concerns thee and thy being;

Dream not of other worlds, what creatures there

Live, in what state, condition or degree.

[To which A dam replies:]

[N ]ot to know at large of things remote

From use, obscure and subtle, but to know

That which before us lies in daily life,

Is the prime wisdom; what is more, is fume,

Or emptiness, or fond impertinence,

And renders us in things that most concern

Unpracticed, unprepared, and still to seek.

(Paradise Lost, 8.173-76, 191-97)

Raphael's description of creation concludes with an emphasis on the human and the physical world. If Milton is the last great poet, in the Western epic tradition, to write about God's making of the world, he is also the first modern author "for whom the act of creation begins to find its center in the human" (Teskey 2006, 29). For this reason, his sublime poetry represents the most original expression of the analogy between poetic and divine creation, and yet, it also anticipates the profound gulf between God's act of making and the authority of human creativity.

\footnotetext{
${ }^{24} \mathrm{~A}$ long and fruitful relation between sublime poetry and natural philosophy has been recently investigated in Porter's monumental work The Sublime in Antiquity (2016). Lucretius is a fundamental link within this tradition of the natural sublime. For the Lucretian influence on Paradise Lost see Hardie (2009) and Quint (2014), although an account of Lucretius's impact on the topos of poetic creation still needs further investigation.
} 


\section{Conclusion}

The examples taken from II mondo creato and Paradise Lost have illustrated how the two poems are alike in considering the fashioning of the world in the Scriptures as a source of rhetorical and experiential sublimity. In their interpretations of the fiat lux, in particular, Tasso and Milton recognize that the narration of the divine command "Let there be light" is not only an example of sublime, elevated rhetoric, but it is also an occasion to reveal the grandeur of a poet's mind, as for the author of Peri Hypsous (9.2). The source of sublime poetry, for Tasso and Milton, is divine light that works through inner illumination to inspire and elevate the poet to an experience of transcendence. The capacity of the poet to create an intense moment of transport, which shortens "the distance between earth and heaven" (On the Sublime 9.4), has a strong emotional impact also in the reader or listener, as Longinus explains in this tractate (1.4). This elevating and overwhelming effect on the reader is the result of the communication of the writer's magnanimous soul through the power of his sublime poetry. However, Tasso and Milton diverge in the way in which they conceive of the transmission of their inspired grandeur and in their respective formulations of the experience of sublimity.

In Tasso's II mondo creato, meraviglia describes the exceptional contemplative transport of the mind, which experiences the sacred by contemplating the traces of the heavenly in the created world. Divine light descends in the spirit of the poet ("nel mi o cuore al berga" 1.21) whoseartistic creation elevates him to the contemplation of the divine. This singular and individual feeling of momentary transcendence of the human condition, affecting both the poet and the reader, produces meraviglia or ekstasis, as Longinus calls the concomitance of astonishment and wonder ( $\mathrm{n}$ the Sublime, 1 ).

Rather than an exceptional and contemplative moment, in Milton's Paradise Lost, sublimity describes a dialogic, often dialectic, confrontation between opposing images, characters, and narrations. As in Tasso's poem, the Miltonic sublime originates from an extraordinary mind inwardly moved by divine light; yet, Milton's notion of sublimity is also indicative of a certain skepticism towards the Longinian notion of ecstasy. The origins of sublime creation in Paradise Lost lie more in Longinus's idea of mimesis as an agon: representation means emulating and repeating the original text by 
staging opposing values, images and contrasting voices, and then resolving them into a synthesis.

Furthermore, the two kinds of sublimity in II mondo creato and $P$ aradise Lost diverge in the relation between poetic creation and matter. Whereas, for Tasso, wonder represents the tendency to move from matter into the transcendental, Milton's sublimity focuses on the materiality of the created universe to mark its distance from immateriality. According to the English poet, mankind's understanding of the divine should be grounded in the physical world, since the divine can only be reached through its radical otherness from matter.

Despite their differences, Tasso's meraviglia and Milton's sublime are alike in their origins-since the experience of being exalted and overwhelmed passes through the materiality of the created worldand they converge again in their mutual yearning for transcendence. Milton's descent into the very heart of matter at the time of its creation aims to grasp the essence of the immaterial through its opposite. By the same token, Tasso's transcending trajectory recoils from matter into something higher, but then turns back into the physical world in order to retrace the presence of the divine within immanence. The fact that the two authors vacillate between one extreme and the other is not to be understood as a sign of their distance. Instead, the reason for this vacillation lies in the very nature of the Longinian sublime, which resides in the tension between immanence and transcendence, materiality and immateriality. By rewriting thefiat lux scene of biblical creation, these two poems by Tasso and Milton are closely related in their attempt to represent the cosmic gap that measures the distance between earth and heaven.

\section{References}

Achinstein, Sharon. 2003. Literature and Dissent in Milton's England. Cambridge: Cambridge University Press.

Ardissino, Erminia. 2003. “PerchéPlotino." In Tasso, Plotino, Ficino. In margine a un postillato, edited by Erminia Ardissino, 13-30. Rome: Edizioni di Storia e letteratura.

Ariosto, Ludovico. 1997. Orlando Furioso e i Cinque canti. Edited by Remo Ceserani and Sergio Zatti. Torino: UTET. 
Boileau-Despréaux, Nicolas. (1674) 2007. Traité du sublime ou du merveilleux dans le discours. In 0 euvres completes. Paris: Firmin Didot Frères [Elibron Classics Replica].

Boitani, Piero. 2007. Prima lezione sulla letteratura. Rome-Bari, Laterza.

Cheney, Patrick. 2018. English A uthorship and theEarly M odern Sublime. Fictions of Transport in Spenser, M arlowe, Jonson, and Shakespeare. Cambridge: Cambridge University Press.

Doran, Robert. 2015. The Theory of the Sublime from Longinus to Kant. Cambridge: Cambridge University Press.

Fish, Stanley. 2001. H ow M ilton Works. Cambridge, MA: Harvard University Press.

Fumaroli, Marc. 1986. "Rhétoriqued'écoleet théoriqueadulte: Remarquessur la réception européenne du traité ‘Du sublime' au XVI et au XVII' siècle." Revue d'H istoire Littéraire de la France 86: 33-51.

Goyet, Francis. 1991-1992. “Le pseudo-sublime de Longin.” Études Littéraires 243: 105-19.

Graziani, Françoise. 1996. “Le miracle de l'art: le Tasse et la poétique de la meraviglia." Revue des Études I taliennes 42 (1/2): 117-39.

Guardiani, Francesco. 1986. "Torquato Tasso. L'umanità della rivelazionenel M ondo creato." C ritica Letteraria 51 (14): 211-24.

Halliwell, Stephen, Donald Russell, and Doreen C. Innes, eds. 1995. A ristotle: P oetics. Longinus: On the Sublime. Demetrius: On Style. Cambridge (MA): Harvard University Press.

Halliwell, Stephen. 2012. Between Ecstasy and Truth. Interpretations of Greek P oetics from H omer to L onginus. Oxford: Oxford University Press.

Hardie, Philip. 2009. Lucretian Receptions: History, the Sublime, Knowledge. Cambridge: Cambridge University Press.

Kates, Judith A. 1983. Tasso and Milton: The Problem of Christian Epic. Lewisburg: Bucknell University Press.

Lehtonen, Kelly. 2016. "Peri H ypsous in Translation: The Sublime in SixteenthCentury Epic Theory." Philological Q uarterly 95 (3/ 4): 449-65.

Lehtonen, Kelly. 2019. “The Satanic Subl ime in Paradise L ost: Tasso, Charisma, A bjection." M odern Philology 116 (3): 211-34.

Leo, UIrich. 1954. "Torquato Tasso alle soglie del secentismo." Studi Tassiani 4: 3-17.

Lewalski, Barbara Kiefer. 2003. The Life of John M ilton: A Critical Biography. Revised edition. Oxford: Blackwell.

Lieb, Michael. 1970. The Dialectics of Creation. Patterns of Birth and R egen eration in Paradise Lost. Amherst: University of Massachusetts Press. 
Luparia, Paolo. 1987. “II 'Mondo creato' poema sapienziale.” Giornale Storico della Letteratura Italiana 164 (525): 1-33.

Milton, John. 1953. Complete Prose W orks of John M ilton [CPW ]. 8 vols. Edited by Don M. Wolfe. New Haven and London: YaleUniversity Press.

Milton, John. (1957) 1975. The Christian D octrine. In Complete Poems and M ajor Prose, edited by Merritt Y. Hughes, 900-1020. Indianapolis: The Odyssey Press.

Milton, John. (1674) 1993. Paradise Lost. $2^{\text {nd }}$ ed. Edited by Alastair Fowler. Harlow: Pearson Longman.

Morace, Rosanna. 2016. "N ote sulla genesi e sulla lingua del M ondo creato." In "In te son nulla." Studi sulla poesia sacra di Torquato Tasso, edited by Marco Corradini and Ottavio Ghidini, 111-38. Rome: Storia e letteratura.

Patterson, Annabel M. 1971. "Tasso and Neoplatonism: The Growth of his Epic Theory." Studies in the Renaissance 18: 105-33.

Platt, Peter G. 1992. “'N ot before either known or dreamt of': Francesco Patrizi and the Power of Wonder in Renaissance Poetics." The Review of English Studies 43 (171): 387-94.

Porter, James I. 2016. The Sublime in Antiquity. Cambridge: Cambridge University Press.

Quint, David. 2014. Inside Paradise Lost. Reading the Designs of M ilton's Epic. Princeton and Oxford: Princeton University Press.

Radzinowic, Mary Ann. (1978) 2015. Toward Samson Agonistes. The Growth of M ilton's M ind. Princeton and Oxford: Princeton University Press.

Ramachandran, Ayesha. 2015. The Worldmakers. Global Imagining in Early M odern Europe. Chicago and London: The University of Chicago Press.

Schwartz, Regina M. 1993. Remembering and Repeating. On M ilton's Theology and P oetics. $2^{\text {nd }}$ ed. Chicago and London: Chicago University Press.

Scianatico, Giovanna. 1994. “II poema 'meraviglioso'. Per un'ipotesi sul M ondo creato." In Dall'idillio alla visione. Passaggi della differenza tra Rinascimento e Barocco in area napoletana, edited by Raffaele Girardi, Giovanna Scianatico, Raffaele Cavalluzzi and Pasquale Guaragnella, 6198. Manduria: Piero Lacaita Editore.

Steadman, John M. 1976. Epic and Tragic Structure in Paradise Lost. Chicago and London: The University of Chicago Press.

Sylvester, Joshua. (1605) 1979. The Divine Weeks and W orks of Guillaume de Saluste, Sieur du Bartas. Vol. I. Edited by Susan Snyder. Oxford: Clarendon Press.

Tasso, Torquato. 1875. Prose diverse. Vol . 2. Edited by Cesare Gausti. Florence: Le Monnier. 
Tasso, Torquato. 1959. Prose. vol. 2. Edited by Ettore Mazzali. Milano and Napoli: Ricciardi.

Tasso, Torquato. 1973. D iscourses on the H eroic Poem. Translation with notes by Mariella Cavalchini and Irene Samuel. Oxford: Clarendon Press.

Tasso, Torquato. 1982. Creation of the World. Edited by Joseph Tusiani. Binghamton: Center for M edieval \& Early Renaissance Studies.

Tasso, Torquato. (1607) 2007. II mondo creato. Vols. I.i-ii. Edited by Paolo Luparia. Alessandria: Edizioni dell'Orso.

Teskey, Gordon. 2006. Delirious Milton. The Fate of the Poet in M odernity. Cambridge (MA): Harvard University Press.

How to cite this article:

Montori, Irene. "Representing Creation, Experiencing the Sublime: The Longinian

Tradition in Tasso and Milton." SEDERI 30 (2020): 69-89.

https:/ / doi.org/ 10.34136/ sederi.2020.4

A uthor's contact: irene.montori@fondazione.uniromal.it

Postal address: Department of European, American and Intercultural Studies - Piazzale Aldo Moro 5- 00185 Rome - Italy 